socioeconomic status on the severity and outcome of community-acquired pneumonia among Egyptian children: a cohort study", Infect Dis Poverty, 3, pp. 3 - 14.

2. Lưu Thị 'Thùy Dương, Khổng Thị Ngọc Mai (2019), "Đặc điểm lâm sàng, cận lâm sàng và các yếu tố liên quan đến mức độ nặng của viêm phổi ở trẻ em từ 2 - 36 tháng tại Bệnh viện Trung Ương Thái Nguyên", Tap chí khoa học và công nghệ, 207(14), tr. $67-72$.

3. Võ Thị Kim Dung (2018), Nghiên cứu đặc điểm lâm sàng, cận lâm sàng và thể tích tiểu cầu trung bình (MPV) trong viêm phổi trẻ em từ 2 tháng đến 5 tuổi, Luận văn Thạc sĩ Y học, Trường Đại học $Y$ Dược Huế.

4. Hoang V.T., Dao T.L. Minodier P. et al (2019), "Risk Factors for Severe Pneumonia According to WHO 2005 Criteria Definition Among Children < 5 Years of Age in Thai Binh, Vietnam: A Case Control Study", Journal of Epidemiology and Global Health, 9(4), pp. 274 - 280.
5. Nguyễn Thành Nhôm, Phan Văn Năm, Võ Thị Thu Hương (2015), "Nghiên cứu đăc điểm lâm sàng, cận lấm sàng và các yếu tố liển quan đến viêm phổi nặng ở trẻ em từ 2 tháng đến 5 tuổi tại bệnh viên đa khoa tỉnh Vĩnh Long", Kỷ yếu các đề tài nghiền cứu khoa học Bệnh viện đa khoa Vính Long, 10, tr. 1 - 10.

6. Nguyễn Hải Thịnh (2015), "Nghiên cứu áp dụng thang điểm viêm phổi do vi khuẩn (BPS) trong viêm phổi trẻ em từ 2 tháng đến 5 tuổi", Luận văn tốt nghiệp Thạc sĩ Y học, Trường Đại học Y Dươơc Huế.

7. Wei S., Shi T., Chen K. et al (2018), "Risk Factors for Severe Community - Acquired Pneumonia Among Children Hospitalized with CAP Younger Than 5 Years of Age", Pediatr Infect Dis J, 176, pp. 1 - 25.

8. World Health Organization (2013), "Cough and difficult breathing", Pocket Book of Hospital Care for Children - Guidelines For The Management of Common Childhood Illness $2^{\text {nd }}$ Edition, pp. 76 - 124.

\title{
KẾT QUẢ PHẪU THUÂTT NộI SOI ĐIỀU TRI CHỬA NGOÀI TỬ CUNG TẠI KHOA SẢN BỆNH VIÊ̂N TRUNG ƯƠNG THÁI NGUYÊN NĂM 2020
}

\section{Nông Thị Hồng Lê**, Nguyễn Thị Nga*, Nguyễn Thị Giang*, Lê Đức Thọ*}

\section{TÓM TẮT}

Mở đâu: Nhằm đánh giá kết quả điều trị phẫu thuật nội soi ở những bệnh nhân chửa ngoài tử cung. Chúng tôi tiến hành nghiên cứu đề tài: "Kết quả phẩu thuật nội soi điều trị chửa ngoài tử cung tại Bệnh viện Trung ương Thái Nguyên năm 2020" Phương pháp: Mô tả cắt ngang 94 bệnh nhân bị thai ngoài tử cung được phẫu thuật nội soi tại Bệnh viện Trung ương Thái Nguyên từ tháng 01/03/2020 đến 31/12/2020. Chúng tôi ghi nhận triệu chứng, tỷ lệ thành công lượng máu mất, thời gian phẫu thuật và biến chứng

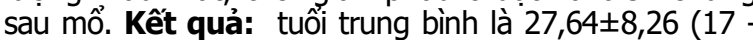
42), tiền sử thai ngoài tử cung 9,57\%, tiền sử đặt dụng dung cụ tử cung $23,40 \%$, tiên sử viêm sinh dục $58,51 \%$, tiển sử hút thai $\geq 2$ lần $36,17 \%$. Tỷ lệ phẫu thuật nội soi thành công $100 \%$, phẫu thuật cắt vòi tử cung chiếm 96,4\%. Không có biến chứng nặng nề sau mổ.

Tư khóa: Phẫu thuật nội soi, chửa ngoài tử cung.

\section{SUMMARY}

RESULT OF INTERIOR SURGERY

SURVEILLANCE AT THAI NGUYEN

CENTRAL HOSPITAL DEPATMENT IN 2020

Introduction: to comment the result of endoscopic surgery in patients with ectopic pregnancy.

*Trường Đại học Y Dược Thái Nguyên

Chịu trách nhiệm chính: Nông Thị Hồng Lê

Email: bsle1978@gmail.com

Ngày nhận bài: 21.01.2021

Ngày phản biên khoa học: 15.3.2021

Ngày duyệt bài: 24.3.2021
Conducting research on the topic of " Result of endoscopic surgery for ectopic pregnancy at Thai Nguyen Central Hospital" in 2020. Methods: Retrospective study of 94 patients who with ectopic pregnancy were endoscopic surgically treated at Thai Nguyen Central Hospital from 01/03/2020 to $31 / 12 / 2020$. We recorded symptoms, the rate of surgical success, rate of blood loss, time of surgery and complications after surgery. Results: the average age $27,64 \pm 8,26(17-42)$, history of ectopic pregnancy $9,57 \%$, history of use of intrauterine devices $23,40 \%$, history of inflammation of the genitals $58,51 \%$, history of suction $\geq 2$ times $36.9 \%$. The rate of successful laparoscopic surgery was $94.0 \%$, and surgical removal of the uterus was $96.4 \%$ ). No serious complications after surgery, the results of pathology for $100 \%$ of cases are ectopic pregnancy.

Keywords: Endoscopic surgery, Ectopic pregnancy.

\section{I. ĐĂT VẤN ĐỀ}

Chửa ngoài tử cung là hiện tượng trứng được thụ tinh và làm tổ ở ngoài buồng tử cung, là một cấp cứu chảy máu trong 3 tháng đâu của thời kỳ thai nghén, nếu không được chẩn đoán và điêu trị kịp thời khối chửa võ đột ngột gây chảy máu trong ổ bụng có thể dẫn đển tử vong.

Tại Việt Nam cũng như trên Thế giới tân suất chửa ngoài tử cung ngày càng tăng lên. Tại Mỹ năm 1970 tỷ lệ chửa ngoài tử cung là 4,5/1000 các trường hợp mang thai, năm 1997 tỷ lệ này đã là 19,7/1000. Ở Việt Nam năm 2000 tỷ lệ chửa ngoài tử cung là 30,7/1000, năm 2002 là 
40,6/1000. Tỷ lê chửa ngoài tử cung tăng có liên quan với các bệnh lây nhiễm qua đường tình dục, đặc biệt là Chlamydia trachomatis, viêm nhiểm tiểu khung, tiền sử nạo phá thai, sử dụng biện pháp tránh thai như đặt dụng cụ tử cung hay mẹ lớn tuổi... Trong những năm gân đây chúng ta đã thấy được sự phát triển vượt bậc của phẫu thuật nội soi với nhiều ưu điểm hơn so với mổ mở như tính thẩm mỹ, độ chính xác, thời gian nằm viện ngắn và giảm các biến chứng sau mổ, phẫu thuật nội soi ngày càng được áp dụng rộng rãi, đặc biệt là trong phẫu thuật điều trị các bênh sản phụ khoa.

Tại Bệnh viện Trung ương Thái Nguyên, phẫu thuật nội soi được triển khai từ năm 2013 và đã áp dụng trong chẩn đoán và điều trị trong một số bệnh lý phụ khoa như: chửa ngoài tử cung, u nang buồng trứng, gõ dính phụ khoa, mở thông vòi trứng, nội soi chẩn đoán... đã có sự tiến bộ qua từng năm. Từ những thực tế trên, chúng tôi tiến hành nghiên cứu đề tài "Kết quả phẫu thuật nội soi điều trị chửa ngoài tử cung tại Bệnh viện Trung ương Thái Nguyên năm 2020" nhằm hai mục tiêu:

1. Mô tả đặc điểm lâm sàng, cận lâm sàng của những bệnh nhân chửa ngoài tử cung được điều trị phấu thuật nội soi tại khoa sản bệnh viện trung ương Thái Nguyên năm 2020.

2. Nhận xét kêt quả điều trị phẫu thuật nội soi chửa ngoài tử cung tại khoa sản Bệnh viện Trung Ương Thái Nguyên năm 2020.

\section{II. ĐỐı TƯợNG VÀ PHƯƠNG PHÁP NGHIÊN CỨU}

1. Đối tượng nghiên cứu. Tất cả những bệnh nhân được chẩn đoán chửa ngoài tử cung, được điều tri phẫu thuât nội soi tai BVTW Thái Nguyên từ tháng 01/03/2020 tới hết tháng $31 / 12 / 2020$.

\subsection{Tiêu chuân lựa chon:}

- Bệnh nhân được chẩn đoán trước mổ là chửa ngoài tử cung

- Được điều trị bằng phẫu thuật nội soi tại BVTW Thái Nguyên từ tháng 01/03/2020 đển hết tháng 31/12/2020.

- Có kêt quả giải phẫu bệnh sau mổ.

- Có hồ sơ bênh án đầy đủ các thông tin.

1.2. Tiêu chuẩn loại trừ: Những bệnh án không đầy đủ thông tin nghiên cứu.

\section{Phương pháp nghiên cứu}

2.1. Thiêt kế nghiên cứu. Nghiên cứu mô tả cắt ngang.

2.2. Cỡ mẫu nghiên cứu. Mẫu nghiên cứu (N) được lấy là toàn bộ bệnh nhân bị chửa ngoài tử cung được chẩn đoán và điêu trị bằng phẫu thuật nội soi tại Bệnh viện viện trung ương Thái
Nguyên từ ngày $01 / 03 / 2020$ - 31/12/2020 có đủ tiêu chuẩn lựa chọn để nghiên cứu.

3. Đạo đức nghiên cứu. Nội dung nghiên cứu đủ điều kiện về đạo đức nghiên cứu y học

\section{KẾT QUẢ NGHIÊN CỨU}

\subsection{Một số đặc điểm của đối tượng} nghiên cứu

Bảng 1. Đặc điểm về tuổi

\begin{tabular}{|c|c|c|c|c|}
\hline \multicolumn{2}{|c|}{ Tuổi } & $\begin{array}{c}\text { Số } \\
\text { lượng }\end{array}$ & $\begin{array}{c}\text { Tỷ lệ } \\
\text { \% }\end{array}$ & $\begin{array}{c}\text { Trung } \\
\text { bình }\end{array}$ \\
\hline \multirow{3}{*}{ Tuổi } & $<25$ & 26 & 27,65 & \multirow{2}{*}{} \\
\cline { 2 - 5 } & $25-35$ & 45 & 47,87 & $27,64 \pm$ \\
\cline { 2 - 4 } Tống & $>35$ & 23 & 24,46 & 8,26 \\
\hline
\end{tabular}

Nhân xét: Tuối trung bình 27,64 $\pm 8,26$, tuổi nhỏ nhất 17, tuổi lớn nhất 42.

Bảng 2. Đặc điểm về số con

\begin{tabular}{|c|c|c|}
\hline Số lân mang thai & Số lượng & Tỷ lệ \% \\
\hline Chưa sinh con & 26 & 27,65 \\
\hline 1 con & 38 & 40,42 \\
\hline 2 con & 21 & 22,34 \\
\hline$\geq 3$ con & 9 & 9,57 \\
\hline Tống & $\mathbf{9 4}$ & $\mathbf{1 0 0}$ \\
\hline
\end{tabular}

Nhận xét: Tỷ lệ thai ngoài tử cung gặp nhiêu nhất ở đối tượng đã có 1 con chiểm $40,42 \%$. Chưa có con nào chiếm $27,65 \%$.

Bảng 3. Phân bố theo tiền sử sản phụ khoa

\begin{tabular}{|c|c|c|c|}
\hline \multicolumn{2}{|c|}{ Tiền sử } & $\begin{array}{c}\text { Số } \\
\text { Iương }\end{array}$ & $\begin{array}{l}\text { Tỷ lệ } \\
\text { \% }\end{array}$ \\
\hline \multirow{3}{*}{$\begin{array}{c}\text { Tiên sử } \\
\text { nạo, hút } \\
\text { thai }\end{array}$} & Chưa lần nào & 35 & 37,23 \\
\hline & 1 lần & 25 & 26,59 \\
\hline & $\geq 2$ lần & 34 & 36,17 \\
\hline \multirow{2}{*}{$\begin{array}{l}\text { Tiền sử mắc } \\
\text { NTĐSDD }\end{array}$} & Có & 55 & 58,51 \\
\hline & Không & 39 & 41,48 \\
\hline \multicolumn{2}{|c|}{ Tiền sử thai ngoài tử cung } & 9 & 9,57 \\
\hline \multicolumn{2}{|c|}{ Tiên sứ có mố cũ ở bung } & 48 & 51,06 \\
\hline
\end{tabular}

Nhân xét: Nghiên cứu của chúng tôi có 35 trường hợp không có tiền sử nao hút thai chiếm $37,23 \%$. Tiền sử đã từng điều trị thai ngoài tử cung 9,57\%, tiền sử có mổ cũ ở bụng chiếm $51,06 \%$. Tiền sử có điều trị nhiễm trung đường sinh dục chiếm $58,51 \%$

Bảng 4: Tiền sử sử dụng biện pháp tránh thai

\begin{tabular}{|c|c|c|}
\hline $\begin{array}{c}\text { Các biện pháp tránh } \\
\text { thai đâ sử dụng }\end{array}$ & $\begin{array}{c}\text { Số } \\
\text { lượng }\end{array}$ & Tỷ lệ \\
\hline Không dưng & 29 & 30,85 \\
\hline Dụng cụ tứ cung & 22 & 23,40 \\
\hline Thuốc uống tránh thai & 9 & 9,57 \\
\hline Bao cao su & 15 & 15,95 \\
\hline Khác & 23 & 24,46 \\
\hline Tống & $\mathbf{9 4}$ & $\mathbf{1 0 0 \%}$ \\
\hline
\end{tabular}


Nhận xét: Tiền sử có sử dụng biện pháp tránh thai là dụng cụ tử cung chiếm $223,40 \%$. Không dùng biện pháp tránh thai nào chiếm 30,85\%.

\subsection{Triệu chứng lâm sàng}

Bảng 5: Triệu chứng cơ năng

\begin{tabular}{|c|c|c|}
\hline Triệu chứng & Số lượng & Tỷ lệ \% \\
\hline Chậm kinh & 13 & 13,82 \\
\hline Chậm kinh + đau bụng & 22 & 23,40 \\
\hline $\begin{array}{c}\text { Chậm kinh + ra huyết } \\
\text { bất thường }\end{array}$ & 27 & 28,72 \\
\hline $\begin{array}{c}\text { Chậm kinh + đauu bụng } \\
\text { + ra huyết }\end{array}$ & 42 & 44,68 \\
\hline Tống & $\mathbf{9 4}$ & $\mathbf{1 0 0}$ \\
\hline
\end{tabular}

Nhận xét: Triệu chứng cơ năng thường gặp chậm kinh, đau bụng, ra huyết âm đạo chiếm tỉ lệ cao nhất là $44,68 \%$.

\section{Bảng 6. Khám thực thê}

\begin{tabular}{|c|c|c|}
\hline Triệu chứng & Số lượng & Tỷ lệ \% \\
\hline Thân từ cung to, mềm & 16 & 17,02 \\
\hline Túi cùng đây và đau & 65 & 69,14 \\
\hline Sờ có khối cạnh tứ cung & 32 & 34,04 \\
\hline
\end{tabular}

Nhận xét: Triệu chứng sờ được khối cạnh tử cung chiếm 34,04, triệu chứng túi cùng đây và đau rõ trong trường hợp rỉ máu hoặc vṍ chiếm $69,14 \%$

Bảng 7. Xét nghiệm hCG và siêu âm

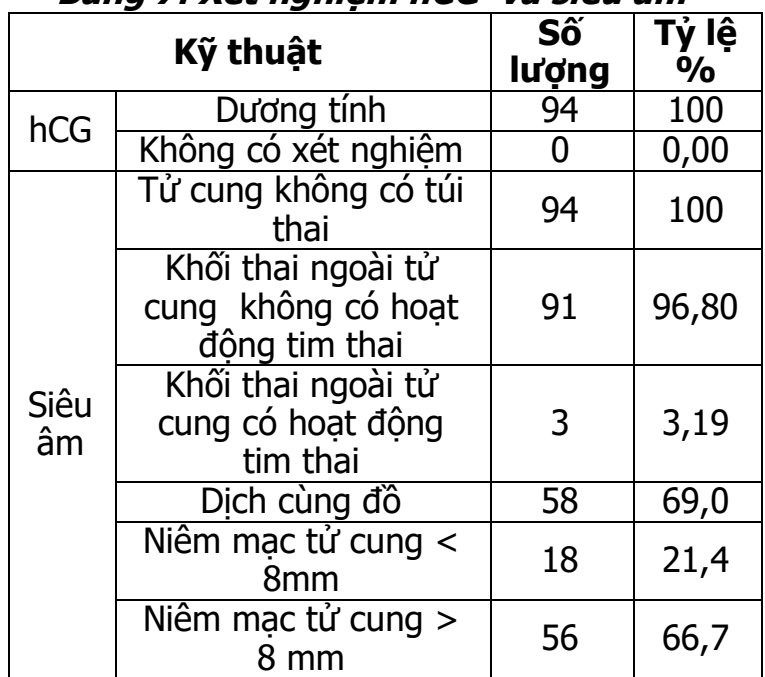

Nhận xét: 94 trường hợp có kết quả hCG dương tính trước khi được phẫu thuật chiếm $100 \%$. Trường hợp trên siêu âm đều không có hình ảnh túi ối trong buồng tử cung $100 \%$. Niêm mạc tử cung > 8mm chiếm tỷ lệ cao 66,7\%, 58 trường hợp có dịch cùng đồ $(69,0 \%)$.

Bảng 8. Vị trí khôi thai ở vòi trứng

\begin{tabular}{|c|c|c|}
\hline Vị trí ở vòi trứng & Số lượng & Tỳ lệ $\%$ \\
\hline Đoạn kẽ & 02 & 2,12 \\
\hline Đoạn eo & 15 & 15,95 \\
\hline Đoạn bóng & 68 & 72,34 \\
\hline
\end{tabular}

\begin{tabular}{|c|c|c|}
\hline Đoạn loa & 14 & 14,86 \\
\hline Tống & $\mathbf{9 4}$ & $\mathbf{1 0 0}$ \\
\hline
\end{tabular}

Nhận xét: Gặp khối chửa ở tất cả các vị trí của vòi trứng, hay gặp nhất là ở đoạn bóng vòi tử cung (72,34\%).

Bảng 9. Tính chất khôi thai ngoài tử cung \begin{tabular}{|l|l|l|}
\hline Tính chất khối thai & Số lượng & Tỷ lệ \% \\
\hline
\end{tabular}

\begin{tabular}{|c|c|c|}
\hline Tinh chất khơi thai & Só lượng & Ty lẹ \% \\
\hline Chưa võ & 29 & 30,85 \\
\hline Đang rí máu & 53 & 56,38 \\
\hline Đã võ & 12 & 12,76 \\
\hline Tống & $\mathbf{9 4}$ & $\mathbf{1 0 0}$ \\
\hline
\end{tabular}

Nhận xét: Có 53 bệnh nhân khối chửa rì máu chiếm $56,38 \%$, Có 12 bệnh nhân khối chửa đã võ nhưng chưa có choáng chiếm tỷ lệ $12,76 \%$ được phẫu thuật.

Bảng 10. Lượng máu trong ổ bụng

\begin{tabular}{|c|c|c|}
\hline Số lượng máu & Số lượng & Tỷ lệ \% \\
\hline Không có máu & 29 & 30,85 \\
\hline$<100 \mathrm{ml}$ & 51 & 54,25 \\
\hline $100-1000 \mathrm{ml}$ & 14 & 14,89 \\
\hline Tống & $\mathbf{9 4}$ & $\mathbf{1 0 0}$ \\
\hline
\end{tabular}

Nhận xét: Số bệnh nhân bị thai ngoài tử cung rì máu có lượng máu $\leq 100 \mathrm{ml}$ chiếm $54,25 \%$. Còn nhóm thai ngoài tử cung võ chưa choáng có lượng máu $100-1000 \mathrm{ml}$ là $14,86 \%$. Những trường hợp này đã được cấp cứu kịp thời và chỉ định mổ nội soi thành công.

\subsection{Kết quả điều trịBảng 11. Phương} pháp phẫu thuật

\begin{tabular}{|c|c|c|}
\hline $\begin{array}{c}\text { Phương pháp phâu } \\
\text { thuật }\end{array}$ & $\begin{array}{c}\text { Số } \\
\text { lượng }\end{array}$ & $\begin{array}{c}\text { Tỷ lệ } \\
\text { \% }\end{array}$ \\
\hline $\begin{array}{c}\text { Cắt lấy khối chứa và vòi } \\
\text { tứ cung tận gốc }\end{array}$ & 82 & 87,23 \\
\hline $\begin{array}{c}\text { Lấy khối huyểt tụ và cắt } \\
\text { vòi tử cung tận gốc }\end{array}$ & 11 & 11,70 \\
\hline $\begin{array}{c}\text { Đốt cầm máu bào tồn vòi } \\
\text { tử cung }\end{array}$ & 01 & 1,06 \\
\hline Tống & $\mathbf{9 4}$ & $\mathbf{1 0 0}$ \\
\hline
\end{tabular}

Nhận xét: $87,23 \%$ các trường hợp mố nội soi của chúng tôi đều cắt vòi tử cung vì vị trí khối chửa nằm ở vòi tử cung, có 01 trường hợp khối thai sảy qua loa chiếm 1,06\% được đốt cầm máu bảo tồn.

Bảng 12. Biến chứng sau mổ

\begin{tabular}{|c|c|c|}
\hline Biến chứng & $\begin{array}{c}\text { Số lượng } \\
\text { BN }\end{array}$ & $\begin{array}{c}\text { Tỉ lệ } \\
\mathbf{( \% )}\end{array}$ \\
\hline Không biến chứng & 93 & 98,93 \\
\hline Chảy máu & 0 & 0 \\
\hline Tụ máu chân trocart & 01 & 1,06 \\
\hline Tốn thương tạng & 0 & 0 \\
\hline Viêm phúc mạc & 0 & 0 \\
\hline Tống số & $\mathbf{9 4}$ & $\mathbf{1 0 0}$ \\
\hline
\end{tabular}


Nhận xét: Tỉ lệ biến chứng sau mổ gặp 01 trường hợp (1,09\%) do 01 trường hợp tụ máu chân trocart.

Bảng 13. Sử dung kháng sinh

\begin{tabular}{|c|c|c|}
\hline $\begin{array}{c}\text { Sử dụng kháng } \\
\text { sinh }\end{array}$ & $\begin{array}{c}\text { Số lượng } \\
\text { BN }\end{array}$ & $\begin{array}{c}\text { Tỉ lệ } \\
\text { (\%) }\end{array}$ \\
\hline Dự phòng & 25 & 26,59 \\
\hline Điều trị & 69 & 73,40 \\
\hline Tống số & $\mathbf{9 4}$ & $\mathbf{1 0 0}$ \\
\hline
\end{tabular}

Nhận xét: Bệnh nhân được sử dụng kháng sinh dự phòng chiếm tỉ lệ 26,59\%, theo phương pháp điều trị chiếm $73,40 \%$.

\section{BÀN LUÂN}

4.1. Đặc điểm lâm sàng của bệnh nhân. Tuổi bệnh nhân từ 25- 35 chiếm đa số 47,87\%, tuổi trẻ nhất là 17 tuổi nhiều nhất là 42. Đây là lứa tuổi sinh đẻ. Tuổi trung bình bị thai ngoài tử cung là 27.64 8.26 (17 -42). Trong nghiên cứu này chúng tôi nhận thấy thai ngoài tử cung hay gặp ở phụ nữ có 1 con là $40,42 \%$, phụ nữ chưa có con nào $27,4 \%$.

Tiền sử nạo hút thai. Một số tác giả cho rằng yếu tố nguy cơ gây thai ngoài tử cung là nạo hút thai nhiêu lần. Trong nghiên cứu này tỷ lệ có tiền sử hút thai là $62.76 \%$. Theo nghiên cứu của Tạ Thị Thanh Thủy (1999) tại thành phố Hồ Chí Minh thì tiền sử nạo hút thai là yếu tố nguy cơ gây chửa ngoài tử cung, nguy cơ tương đối là 3,1. Theo Lê Thị Hòa nghiên cứu bênh chứng 260 trường hợp cho thấy nhóm nạo hút thai nguy cơ chửa ngoài tử cung cao gấp 2,97 lần so với nhóm không có tiền sử nạo hút thai.

Nạo hút thai không phải là nguyên nhân gây ra thai ngoài tử cung cho những lần tiếp theo, tuy nhiên nếu nạo hút thai không an toàn để gây ra tình trạng viêm nhiễm sinh dục, quá trình viêm nhiễm lẩu ngày có thể để lại hậu quả chít hẹp vòi trứng hay dính buồng tử cung, đó là những nguyên nhân làm tăng tỷ lệ vô sinh và thai ngoài tử cung hiện nay. Do vậy việc nạo hút thai hiện nay cần có biện pháp nhằm giảm tỷ lệ này, cũ̃ng như ngày càng phải làm tốt công tác tuyên truyền về sức sức khỏe sinh sản với các đối tượng trong độ tuổi sinh đẻ, mà đặc biệt với đối tượng vị thành niên và chưa lập gia đình. Đồng thời nâng cao trình độ nhân viên y tế để đảm bảo chất lượng trong quá trình làm thủ thuât và đảm bảo nao hút thai an toàn.

Tiền sử mổ cũ ổ bung. Trong nghiên cứu này tỷ lệ bệnh nhân có mổ đẻ cũ là $51,06 \%$, nhiều tác giả cho rằng mổ đẻ là yếu tố nguy cớ gây thai ngoài tử cung, do mổ đẻ cũ có thể dẫn đến viêm dính, ảnh hưởng đến độ thông và chức năng vòi tử cung, gây cản trở sự di chuyển của trứng đã thụ tinh di chuyển về buồng tử cung.

Tiền sử mắc nhiễm trùng đường sinh dục dưới. Theo nghiên cứu của chúng tôi thì bênh nhân có tiền sử nhiễm trùng đường sinh dục dưới là $58,51 \%$

Triệu chứng lâm sàng. Tam chứng cổ điển của thai ngoài tữ cung: chậm kinh, đau bụng, ra huyết là triệu chứng điển hình của bênh nhân chiếm tỷ lệ cao nhất. Tuy nhiên có những bệnh nhân chỉ có biểu hiện rối loạn kinh nguyệt mà bản thân bệnh nhân không xác định được có chậm kinh hay không, chậm kinh gặp ở tất cả các bệnh nhân, triệu chứng kèm theo có thể là đau bụng hoặc ra huyết, tỷ lệ chậm kinh ra huyết là $28,72 \%$, đau bụng chiếm tỷ lệ $44,68 \%$, khi thăm khám thực thể có $34,04 \%$ phát hiện khối cạnh tử cung, có 65 trường hợp có dấu hiệu cùng đồ đầy và đau găp trong thai ngoài tử cung có dấu hiệu vỡ chảy máu trong ổ bụng. Tương tự như nghiên cứu của Mark Pearlman và Resad thì triệu chứng đau bụng thường gặp nhiều nhất chiếm $90 \%$ các trường hợp, đau bụng và ra huyết gặp ở 65-70\% các trường hợp thai ngoài tử cung và thường gặp nhất là khi khối chửa võ.

Cận lâm sàng. Triệu chứng điển hình giúp chẩn đoán chính xác thai ngoài tử cung dựa vào lâm sàng và cận lâm sàng, trên siêu âm, nhìn không thấy túi ối nằm trong buồng tứ cung chiếm $100 \%$. Niêm mạc tử cung $>8 \mathrm{~mm}$ chiếm $66,7 \%$. Dịch cùng đồ tương ứng với hình thái lâm sàng chưa võ hoặc rỉ máu.

Vị trí thai ngoài tử cung. Bình thường hiện tượng thu thai tự nhiên xảy ra ở $1 / 3$ ngoài ống dẫn trứng, cụ thể vị trí đoạn bóng của ống dẫn trứng. Sau khi noãn và tinh trùng đã thụ tinh được gọi là trứng thụ tinh rồi dần dần phát triển thành phôi thai, sau khi trứng thu tinh sẽ di chuyển dần về tử cung để rồi làm tổ. Một khi sự di chuyển này bị trì trệ hay không có sự di chuyển, trứng đã thụ tinh cứ tiếp tục phát triển lớn dần phát triển thai, phôi thai và rau trong túi thai, định vị ngay ở ống dẫn trứng chiếm $97 \%$ thai ngoài tử cung xảy ra ở ống dần trứng. Túi thai phát triển hình thành các gai rau ăn sâu vào lớp niêm mạc của ống dẫn trứng. Do nội mạc ống dẫn trứng không có vị trí giải phẫu thích hợp giống như nội mạc tử cung, nên nguy cơ võ và xuất huyết trong thai ngoài tử cung luôn luôn xảy ra. Trong nghiên cứu này tỷ lệ thai ngoài tử cung ở vòi trứng chiếm $100 \%$, tại vòi trứng thai nằm ở đoán bóng chiếm 72,34\%.

\subsection{Kết quả phẫu thuật}


Kêt quả phẫu thuật: nội soi thành công 94 trường hợp chiếm $100 \%$.

So sánh tỷ lệ thành công với các tác giả khác

\begin{tabular}{|c|c|c|c|c|}
\hline \multirow{2}{*}{$\begin{array}{c}\text { Kết quả phâu } \\
\text { thuật }\end{array}$} & \multicolumn{2}{|c|}{ Thành công } & \multicolumn{2}{|c|}{ Thất bại } \\
\cline { 2 - 5 } & $\begin{array}{c}\text { Sớ } \\
\text { lương }\end{array}$ & $\begin{array}{c}\text { Tỷ lệ } \\
\text { \% }\end{array}$ & $\begin{array}{c}\text { Số } \\
\text { lượng }\end{array}$ & $\begin{array}{c}\text { Tỷ lệ } \\
\text { \% }\end{array}$ \\
\hline $\begin{array}{c}\text { Võ Doãn Mỹ } \\
\text { Thạnh (2010) } \\
\text { n= 158 [5] }\end{array}$ & 157 & $99,4 \%$ & 1 & 0,6 \\
\hline $\begin{array}{c}\text { Pham Mỹ Hoài } \\
\text { (2013) } n= \\
103[6]\end{array}$ & 101 & 98,1 & 2 & 1,9 \\
\hline $\begin{array}{c}\text { Nguyên Thị Bình } \\
\text { (2018) } n=84\end{array}$ & 79 & $94,0 \%$ & 5 & $6.0 \%$ \\
\hline
\end{tabular}

Thành công chúng tôi chiếm $100 \%$, của Võ Doãn Mỹ Thạnh $99.4 \%$, của Nguyến Thi Bình (2018) là $94.0 \%$, thất bại của các tác giả là do các trường hợp có vết mổ cũ nhiều lần, viêm dính nhiều nên không thực hiện được qua nội soi. Qua đây cho thấy rằng trình độ chuyên môn của các bác sỹ ngày càng nâng cao cũng như tiên lượng khi chỉ định phẩu thẫu nội soi tốt nên tỷ lệ thành công ngày càng cao.

Phương pháp phẫu thuật. Trong nghiên cứu của chúng tôi có 82 trường hợp phẫu thuật cắt vòi tử cung tận gốc chiếm $87,23 \%$, có 01 trường hợp khối thai sảy qua loa có chảy máu ít nên đốt cầm máu bảo tồn vòi tử cung. Theo kêtt quả nghiên cứu của Bệnh viện quân y tỷ lệ bảo tôn được vòi tử cung là $8,9 \%$. Theo Pham Mỹ Hoài cắt vòi tử cung chiếm $79,6 \%$, bảo tồn vòi tử cung được $11,7 \%$ vì theo tác giải đa số trường hợp bệnh nhân đến sớm, khối thai chưa võ. Điều đó cho thấy tỷ lệ thành công trong phẫu thuật nội soi, bảo tồn được vòi tử cung phụ thuộc vào thời gian đến viện sớm hay muộn, khối thai đã võ hay chưa.

\section{Hâu Phẫu}

5.1.Biến chứng sau mổ. Tỉ lệ biến chứng sau mổ gặp 01 trường hợp $(1,06 \%)$ do 01 trường hợp tụ máu chân trocart đã được xử lý băng ép tại buồng bệnh

Đỗ Khẳc Huỳnh ghi nhận một trường hợp tổn thương động mạch chậu ngoài trong mổ phải chuyển mổ mở. Nguyễn Bình An 2 trường hợp biến chứng $(1 \%), 01$ do tụ chân trocart, 01 do viêm phúc mạc hậu phẫu.

Qua những thống kê trên có thể thãy rằng tuy tỉ lệ tai biến và biến chứng trong mổ nội soi là không cao song đã gặp nhiều tai biến lớn như tổn thương ruột, tổn thương niệu quản, tổn thương mạch máu, viêm phúc mạc ...

Theo chúng tôi để hạn chế tối đa tai biến trong mổ và biến chứng sau mổ nội soi nói chung thiết nghĩ cần có chỉ định đúng, nắm vững giải phẫu, không nên cố phẫu thuật những trường hợp khó, dính nhiều, vượt khả năng của phẫu thuật viên...những trường hợp mổ khó, có dính nhiều cần phải cân nhắc chuyển mổ mở ngay để hạn chế tai biến. Sau mổ cần theo dõi sát bệnh nhân nhằm phát hiện sớm biến chứng để xử lý kịp thời.

5.2. Sử dụng kháng sinh. Tỉ lệ dùng kháng sinh theo phương pháp dự phòng chiếm $26,59 \%$. Số còn lại $73,40 \%$ sử dụng kháng theo phương pháp điêu trị

Theo Đỗ Khắc Huỳnh tỉ lệ dùng kháng sinh theo phương pháp dự phòng ngắn ( $<5$ ngày) chiếm 95,3\%, theo phương pháp dự phòng dài (5 - 7 ngày) chiếm 4,7\%.

Trong nghiên cứu của Đỗ Thị Ngọc Lan, tỉ lệ sử dụng kháng sinh theo phương pháp dự phòng rất cao lên tới $98,6 \%$, chỉ có $1,4 \%$ dùng kháng sinh theo phương pháp điều trị.

Nghiên cứu của chúng tôi thì việc dùng kháng sinh dự phòng còn thấp khác với các nghiên cứu khác điêuu này lý giải việc dùng kháng sinh theo thói quen của các bác sĩ đã làm giảm ý nghĩa của phẫu thuật nội soi Vì vậy qua đây tôi cũng kiến nghị về việc sử dụng kháng sinh cho bệnh nhân trong PTNS để bệnh nhân sớm trung tiện, có thể ăn uống sớm và rút ngắn thời gian nằm viện sau mổ. Đây là một ưu điểm lớn của PTNS.

\section{KẾT LUÂ̂N}

\section{1. Đăcc điểm lâm sàng}

- Độ tuổi trung bình 27,64士 8,26 (17 - 42), thường gặp ở những người đã có 1 con chiếm $40,42 \%$, có tiền sử sử dụng biện pháp tránh thai là DCTC $23,40 \%$, tiền sử hút thai $\geq 2$ lần $36,17 \%$

- Các triệu chứng điển hình của thai ngoài tử cung rõ như: chậm kinh đau bụng ra huyết $44,68 \%$, đau bụng là triệu chứng thường gặp $67,10 \%$.

- Xét nghiệm hCG dương tính có tỷ lệ 100\%, siêu âm phát hiện khối cạnh tử cung $92,4 \%$, có dịch cùng đồ $69,0 \%$

\section{Kết quả phẫu thuât nội soi}

- Phương pháp phẫu thuật nội soi thành công 94 trường hợp có tỷ lệ $100 \%$

- Thai ngoài tử cung gặp chủ yếu đoạn bóng vòi trứng $72,43 \%$, đã có hiện tượng rỉ máu 56,38\%.Khối chửa chưa võ̃ 29 trường hợp chiếm $30,85 \%$ được chẩn đoán thai ngoài tử cung võ nhưng chưa có choáng là 12 bệnh nhân chiếm $12,76 \%$, chúng tôi vẫn cố gắng để phẫu thuật nội soi và thành công cả 12 trường hợp. 
- Không gặp tai biến và biến chứng nặng trong và sau mổ, có 01 trường hợp chiếm chảy máu chân Trocart rốn sau mổ phải băng ép không cần khâu lại.

- Nhìn chung phẫu thuật nôi soi: dễ quan sát ổ bụng và vòi trứng bên đối diện phẫu thuật nhẹ nhàng, chính xác, vết mổ nhỏ, thời gian phục hồi nhanh, giảm liều lượng và số lượng kháng sinh, giảm các biến chứng do phẫu thuật và sau mổ, tính thẩm mỹ cao.

\section{TÀI LIÊU THAM KHẢO}

1. Phàm văn Lình (2004), "Giải phẫu và sinh lý của hệ sinh sản nữ", Nội tiết học sinh sản", NXBY học, tr. 166-184.

2. Lế Anh Tuấn (2004). Hút điều hòa kinh nguyệt có biến chứng sớm và hậu quả chửa ngoài tử cung ở 3 bệnh viện Phụ sản ở Hà Nội. Tạp chí Y học thực hành số 482, tháng 7/2004, 16 -19.3.

3. Nguyễn Đức Vy (2012), "Chửa ngoài tử cung", Bài giảng sản phụ khoa, NXB y học, tr. 269-281.

4. Phan Trường Duyệt (2007), " Phẩu thuật ở vòi trứng", Phẫu thuật sản phụ khoa, NXB y học, tr. 363-384.

5. Võ Doã̃n Mỹ Thạnh (2010), "Tình hình phẫu thai ngoài tử cung tại Bệnh viện Nhân Dân Gia Đinh từ 01/2009 đến 04/ 2010" Y hoc Thành Phố Hồ Chí Minh. Tập 14. Phụ bản của số 4. 2010. Tr. 43-48.

6. Phạm Mỹ Hoài (2013), "Đánh giá kết quả phẫu thuật nội soi bệnh lý chứa ngoài tử cung tai Bênh viên Trường Đại học Y Dược Thái Nguyên", Tạp chí Khoa học và Công nghệ tr.177-183.

7. Vũ Văn Du (2011), "Phẩu thuât nội soi điều trì bảo tồn vòi tử cung trong chữa ngoài tử cung bằng phẫu thuâtt nội soi", Luận án tiến sỹ y học, Đai học y Hà Nội.

8. Hà Dưy Tiến, Pham Thanh Hiên(2013), "Đăc điểm lâm sàng và̀ môt số yếu tố liên quan đến chửa ngoài tử cung tại Bệnh viện Phụ Sản Trung ương 2010"Luận án chuyển khoà II, Đ̇ại học Y Hà Nội, Tạp chí nghiên cứu Y học

9. Mark Pearlman, Judith E.Tintinalli, Palmela L. Dyne (2003). Ectopic pregnancy. Obstetric \& Gynecologic emergencies: diagnosis and management: $217-225$.

\section{ĐÁNH GIÁ TÌNH TRANG SẮT VÀ FERRITIN HUYẾT THANH Ở BỆNH NHÂN SUY THÂ̂N MẠN CHƯA ĐIỀU TRI THAY THẾ TẠI BỆNH VIỆN TRUNG ƯƠNG THÁI NGUYÊN}

\section{TÓM TẮT}

Mục tiêu: Phân tích mối liên quan giữa sắt và ferritin huyết thanh với tình trang thiếu máu trên bệnh nhân suy thận mãn chưa điêu trị thay thế. Đối tương và phương pháp nghiên cứu: Phương pháp nghiên cứu mô tả cắt ngang tiến hành trên 46 bệnh nhân được chẩn đoán suy thân man giai đoan III, IV chưa điều trị thay thế (chưa lọc máu chu kỳ), điều trị nọi trú tai khoa Thân - Tiết niêu - Bênh viện Trung ương Thái Nguyên. Kết quả và kết İuận: Nồng độ sắt trung bình là $12,41 \pm 12,04 \mu \mathrm{mol} / \mathrm{l}$. Tỷ lệ bệnh nhân có nồng độ sắt huyết thanh giảm là $32,6 \%$. Không có sư khác biệt về nồng độ sắt huyết thanh giữa nam giới và nữ giới và giữa các độ tuổi. Nồng đồ ferritin trung bình là $461,43 \pm 343,75 \mathrm{ng} / \mathrm{ml}$. Có $26,1 \%$ bênh nhân có dự trữ sắt thấp (nồng độ ferritin < 200 $\mathrm{ng} / \mathrm{ml}), 32,6 \%$ bệnh nhân có dự trữ sắt trung bình (nồng đô ferritin từ 200-500 $\mathrm{ng} / \mathrm{ml}$ ) và $41,3 \%$ bênh nhân có tăng dự trữ sắt (nồng độ ferritin $\geq 500 \mathrm{ng} / \mathrm{ml}$ ).

*Trường đại học Y Dược Thái Nguyên Chịu trách nhiệm chính: Nguyễn Thị Ngọc Hà Email: hanguyengoc75@gmail.com Ngày nhân bài: 22.01.2021

Ngày phản biên khoa họ: 18.3 .2021

Ngày duyệt bài: 29.3.2021
Nguyễn Thị Hải Yến*, Nguyễn Thị Ngọc Hà*, Lâm Thị Thu Hương*, Nguyễn Thu Hà*

Nồng độ ferritin huyết thanh có sự khác biệt giữa nam giới và nữ giới (nam lớn hơn nữ). Không có mối tương quan giữa nồng độ sắt và ferritin huyết thanh $p>0,05$. Không thấy mối liển quan giữa nông độ sắt và ferritin huyết thanh với các mức độ thiếu máu.

Tư khóa: Suy thận mạn, sắt, ferritin huyết thanh

\section{SUMMARY}

EVALUATION OF IRON AND FERRITIN

PLASMA STATUS IN CHRONIC KIDNEY

DISEASE PATIENTS WITHOUT

SUBSTANCING TREATMENT IN

THAI NGUYEN GENERAL HOSPITAL

Objective: To analyze the relationship of serum iron and ferritin to anemia status in patients with untreated chronic renal failure. Objects and research methods: Descriptive research methods, the study was conducted on 46 patients diagnosed with stage III and IV chronic kidney failure without replacement treatment, inpatient treatment at the Department of Kidney - Urology - Thai Nguyen General Hospital. Results and conclusions: Average iron concentration is $12.41 \pm 12.04,0 \mu \mathrm{mol} / \mathrm{L}$. The proportion of patients with reduced serum iron concentrations was $32.6 \%$. There is no difference in serum iron levels between men and women and between ages. The mean ferritin concentration was 